\title{
Clinical assessments on the dento-maxillary anomalies
}

Department I - preclinical disciplines, Faculty of medicine Constanţa

\begin{abstract}
.
The dento-maxillary anomalies, through their characteristics, ie widespread population mass, the impact that occurs at a personal level and in society and the etiological factors, have become a public health problem, ranking first in dental diseases, prior to dental caries and periodontitis. The prevalence of the dentomaxillary anomalies vary by study population, age group, geographical environment, socio-economic factors and the historical moment of the research. This clinical study was conducted over a period of five years, from 2006 to 2011, on a number of 320 study models, for diagnosis and treatment strategies. The study allowed the assessment of increasing trends of dentomaxillary anomalies, with a frequency of $44 \%$ in large cities, while in subjects with caries and periodontitis, the index is $41 \%$. The large percentage differences reported between some authors are mainly due to patients, but also to different research methods, doctors training and errors of interpretation. The orthodontic treatment should answer to the expectations of the patient, thus to restore the morpho-functional integrity and the dentomaxillary functions, with minimal biological sacrifice.
\end{abstract}

Keywords: dento-maxillary anomalies -clinical considerations

\section{Iliescu D.M.}

Department of Anatomy, Faculty of medicine, University "Ovidius" Constanţa, Romania

Aleea Universitatii, Nr. 1, Campus B, Constanța, Romania dan@anatomie.ro

\section{Introduction}

The dento-maxillary anomalies (DMAn) and deformities are first among the dental diseases, prior to dental caries and periodontitis, with overall rate ranging between 23 to $80 \%$. The epidemiological study of the dento-maxillary anomalies has a particular importance, both scientifically and practically, having a fundamental role in: assessing the health of the population and the development directions, developing and implementing preventive health programs, evaluating results obtained in preventive and curative orthodontics. The dentomaxillary anomalies have become a public health issue that involves: the determination of the level of expansion within population (prevalence), the needs and requirement of treatment, the dento-maxillary anomalies severity index, the index of treatment complexity and treatment priorities; the ratio of these factors should assess the needs of medical personnel, equipment and appropriate units able to carry out these activities and, not the least financial resources. The prevalence of the dento-maxillary anomalies vary by population, group age, geographical environment, socio-economic and historical moment. It was concluded that in highly developed countries, the frequency of the dento-maxillary anomalies is higher than in developing and underdeveloped countries. 
Material and method

The clinical study was conducted over a period of five years from 2006 to 2011 based on resolved cases from the "Fils Plus" Dentistry - Orthodontics Clinic in Izmail, Ukraine. The study material consisted of a total of 320 study models for diagnosis and treatment strategies; we also used panoramic radiography, Damon system, facial modeling and laser "Optodan". The specimens were obtained by standard spoons fingerprinting of the alveolar arches. The most commonly used impression materials were fast setting group alginates (eg Ypeen Premium Spofa Dental), but, in special situations, it can be used any silicone material.

\section{Results and discussions}

The analysis of the 320 cases that have been treated showed that the most representative abnormalities were the distal occlusion (46.3\%), the mesial occlusion $(6.6 \%)$, the open occlusion $(1.5 \%)$, the deep covered occlusion $(21.6 \%)$, cross bite occlusion $(9.8 \%)$, shape anomalies $(3 \%)$, teeth inclusion (4\%), supernumerary teeth $(1 \%)$, diastemas $(1.5 \%)$. The anodontia was met in a percentage of $4.7 \%$ of cases, $1.22 \%$ in deciduous dentition and $3.48 \%$ in the case of permanent dentition (Figure 1).

In 126 cases $(39.38 \%)$ the patients were aged 8 to 10 years, 98 patients (30.62\%) were aged $12-14$ years, 50 patients $(15.62 \%$ of cases) were age under 8 and 46 patients (14.38\%) were aged $19-20$ years.

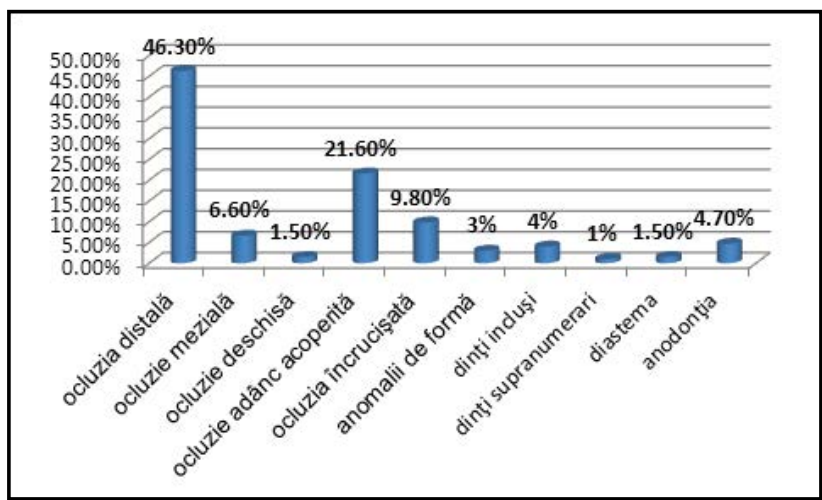

Figure 1 - The frequency of the DMAn related to the type (personal results).

The correlation with literature shows that, in temporary dentition, percentages vary greatly in different countries (Table I).

Table I - The frequency of the DMAn related on age (deciduous dentition).

\begin{tabular}{|l|c|c|c|}
\hline \multicolumn{1}{|c|}{ Age } & Author & Country & Percentage \\
\hline 3-5 years & Dorobăţ & Romania & $38.6-76.9$ \\
\hline 7 years & Hekinheino & Finland & $23-34$ \\
\hline- & Miotti & Italy & 51 \\
\hline temp. dent. & Horosilkina & Russia & 24 \\
\hline temp. dent. & Magnuson & Iceland & 11 \\
\hline 6-11 years & Proffit & U.S.A. & 75 \\
\hline up to 8 years & Mocanu & Ukraine & 15.62 \\
\hline
\end{tabular}

We notice a highly variable percentage of temporary dental disorders, between $11 \%$ in Iceland (Magnuson), 15.62\% in Ukraine (Mocanu, a percentage resulted from personal cases), $75 \%$ in the U.S. [1] and $76.9 \%$ in Romania [2]. Note that in the U.S. this percentage reaches $75 \%$ ), while the percentage is $51 \%$ in Italy, [3] stating that they are permanent abnormalities. The low percentage reported in some countries may be related to medical addressability, in these countries existing national programs that financially support the dento-maxillary treatment. The high percentage in Romania, given by [2], is maximal, between 38.5 to $76.9 \%$ and only at the age of 3-5 years. In terms of percentage of $75 \%$ given by [1], is because it includes a segment of the 
mixed dentition.

Mixed dentition showed smaller variations, the percentage being $38.9 \%$ in Finland, $39.38 \%$ in Ukraine (4 personal cases) and slightly increased in Russia, 49\% [5] (Figure 2).

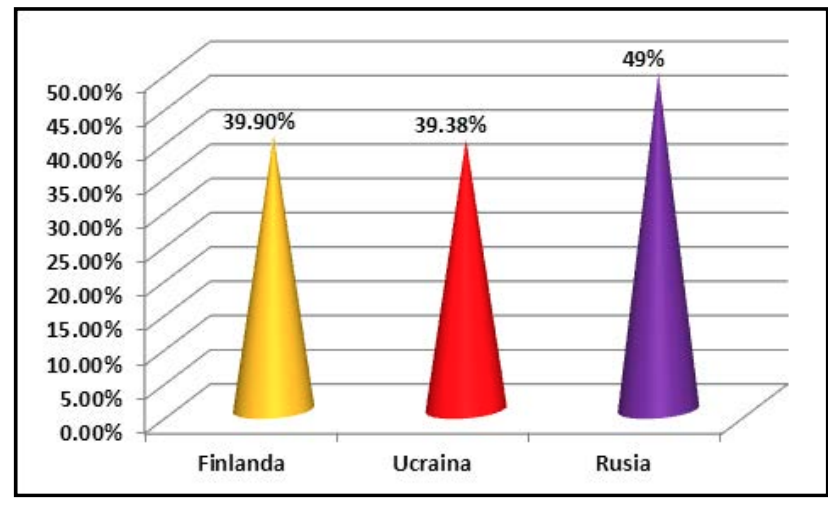

Figure 2 - The frequency of the DMAn related on age (mixt dentition).

The permanent dentition shows an increased variability of the percentages cited in the literature.

In the permanent dentition, the DMAn frequency ranges from $43.1 \%$ in Germany [6] and $90 \%$ in India (Bhalajhi). It is surprising the high percentage of DMAn in Scandinavian countries, ranging from 58\% in Finland (after Myllarniemi) and $78 \%$ in Norway (after Grude), large percentages compared to other countries (excluding India) are also in Sweden, 74.5\% [7] and Denmark, 70\% (Roling), while for the rest of Europe these percentages are 43.1 to $52 \%$ in Germany $[6,8], 52 \%$ in Iceland (Magnuson), 58-59\% in England [9], Russia [5] having the lowest percentage (35\%). In Romania, the statistic is between $41.9 \%$ [10] and 73.6\% [2]; a large percentage, of $72 \%$, is also given by [11] while [12] gives a percentage of $50-60 \%$. This leads us to assume that, in addition to geography, race and ethnicity, a significant role is carried out by the geographical area and time period in which the statistics were performed. This is best seen in India, where Bhalajhi gives a very large percentage, ranging from 19.6 to $90 \%$ of cases (Table II).

Considering the literature, primary anodontia is found in a frequency ranging from 0.08 to $1.55 \%$ in temporary dentition and from 2.3 to $11.3 \%$ in permanent dentition. This percentage varies by ethnicity and race. There is also a difference according to the category of the teeth. Thus, for the upper lateral incisors it occurs in $25 \%$ of cases, for the upper premolars in $20 \%$ of cases, for the central lower lateral incisors in $6.5 \%$ and the anodontia of the lower premolars in $40-50 \%$ of cases. Female-male ratio is $3 / 2$.

Table II - The frequency of the DMAn related on age (permanent dentition)

\begin{tabular}{|l|c|c|}
\hline Author & Country & Percentage \\
\hline Korkhaus & Germany & 43.1 \\
\hline Taas Hana & Germany & 52 \\
\hline Thylander & Sweden & 74.5 \\
\hline Roling & Denmark & 70 \\
\hline Grude & Norway & 78 \\
\hline Myllarnyemi & Finland & 58 \\
\hline Magnuson & Iceland & 52 \\
\hline Haynes-Foster & England & $58-59$ \\
\hline Horosilkina & Russia & 35 \\
\hline Bhalajhi & India & $19.6-90$ \\
\hline Mocanu & Ukraine & 55 \\
\hline
\end{tabular}

\section{Conclusions}

There is a growing trend of dento-maxillary anomalies, with variations from one community to another. The variability manifests itself in relation to the modern and dento-maxillary health. In large cities, the dento-maxillary anomalies frequency is $44 \%$, while in subjects with caries and periodontitis, the index is $41 \%$. The significant differences reported between some authors are mainly due to patients, but also to different research methods, training and mistakes of interpretation. The absence of uniform methods of analysis and different diagnostic classifications lead to different results. Increased frequency of these disorders requires training and the 
establishment of effective and rapid technology and further prophylaxis. The orthodontic treatment goal should respond to the needs of any dental treatment and to the morpho-functional integrity, together with the restoration of dento-maxillary functions, with minimal biological sacrifice.

There are several reasons that lead to orthodontics, such as:

- Biomechanics: normally, the occlusal forces must act in the long axis of the tooth. If from various causes teeth axis undergoes changes (gradients, rotation), the forces acting on them are nonphysiological and therefore, sooner or later, the teeth and their periodontal support is lost. Understanding the application of this principle allows us to avoid complications and increase the treatment effect by applying the appropriate device.

- Biological: the sacrifice of dental tissue is minimal or absent.

- Aesthetic: the modification of the position of frontal teeth, with disagreeable effect (rotation) can be solved successfully, but not with immediate success. damage.

- Prophylaxis: avoid further periodontal

- Occlusion: keeping normal occlusion curves, with leveling and alignment of teeth; if properly designed, it can induce extensive changes of guides (closing, opening).

A more realistic impression of the level of health education is essential in order to choose the moment of treatment and the application of devices, the decision being also conditioned be the habits of oral hygiene.

\section{References}

1. Profitt, W.R. \& Field, H.W. (1993). The Biological Basis of Orthodontic Therapy. Contemporary Orthodontics. 48, 266-288.

2. Scântei-Dorobăț, V. and colab. (1998). Revista
Stomatologică. XXXV(2), 22-25.

3. Miotti, B. (1968). Étude expérimentale sur les effets des forces mécaniques appliquées en O.D.F.: demonstration pratique de la méthode nommée photoelastographique, Orthodont. Franç.

4. Mocanu, S. (2013). Tulburări de dezvoltare ale aparatului dento-maxilar şi posibilităţi de redresare. $\mathrm{PhD}$ Thesis, Constanța.

5. Horosilkina, F.E. (2006). Ortodontia - MIA, Moscva.

6. Korkhaus, G. (1963). L'apport europpéen au problème profilactique en O.D.F. Rev.franç. Odonto-stomat.

7. Thylander, B. (1990). A longitudinal study of malocclusion in relation to signs and symptoms of craniomandibular disorders in children and adolescentes. Eur.J.Orthod. 12, 399-407.

8. Taatz, H. (1961). Bewährte Methoden in der orthopädischen. Profilaxie und Frühbehandlung. Dtsch. Stomat.

9. Haynes, S (1986). A cephalometric study of mandibular changes in modified function regulator treatment. Am. J. Orthod. 90-93.

10. Schapira, M. \& Leheni, V. (1959). Cazuri clinice rezolvate prin terapia extracțională. Stomatologia.

11. Firu, P. (1996). Examenul modelelor în anomaliile stomatologice. Revista stomatologică. LV(4), 28-31.

12. Cocârlă, E. (2002). Aparate ortodontice fixe. Cluj: Ed. Medicală Universitară. 